\title{
Muhasebe Meslek Mensuplarının Meslek Yüksekokulu Muhasebe Programı Öğrencilerinden Beklentileri: Kayseri İlinde Bir Araştırma
}

Gülsevil YILDIZ*

\section{ÖZET}

Bu çalışmada Kayseri il merkezinde faaliyette bulunan bağımsız SMMM'lerin bakış açısıyla, meslek yüksekokulu (MYO) muhasebe bölümü mezunlarının mesleki yeterliliklerini ve meslek mensuplarının mezunlardan beklentilerini tespit etmeye yönelik bir alan çalı̧̧ması yapılmıştır. Çalışmamızda, ögrencilerin piyasa ihtiyaçlarına cevap verebilecek ve muhasebe meslek mensuplarının iş yükünü hafifletmeye yardımcı olacak nitelikte yetiştirilmesine katkıda bulunmak amaçlanmıştır. Araştırmamızda muhasebe meslek mensuplarının MYO muhasebe bölümlerinde verilen eğitim ve ögretimi genel anlamda yetersiz bulduklarl ve özellikle "uygulamalı eğitime" ağırlı verilmesini istedikleri tespit edilmiştir. Ayrica meslek mensuplarının istihdam edecekleri mezunlarda "bilgi ve tecrübeden" çok, "güvenilir, işini seven, çalışkan ve sorumluluk sahibi, yeniliklere ve öğrenmeye açı" olma gibi niteliklere öncelik verdikleri belirlenmiştir.

Anahtar Kelimeler: Muhasebe Mesleği, Muhasebe Ĕ̆itimi, MYO Muhasebe Programı

JEL Sinıflandırması: $M 40, M 41$

Accounting Professionals Vocational School Accounting Program Expectations Of Students: An Apllication Center Of Kayseri

\section{ABSTRACT}

In this study, from the point of the independent CPAs functioning in the center of Kayseri,a field study was conducted to determine the professional competence of the graduate students of accounting program and the expectations of the self-employed from the graduate students.In our study,we aimed to contribute to the training of the graduates qualified enough to respond to the requirements of the market and help reduce the workload of the self-employed. In our research, it was determined that the accountants, in general, found the training conducted in the accounting program of the Vocational Schools insufficient and would like us especially to emphasize the hands-on-learning. In addition, it was also found that the self-emloyed are seeking graduates who are accredited, diligent, loving his/her job, having a sense of responsibility and open to innovations and learning to employ rather than work with knowledgeable and experienced candidates.

Keywords: Accounting Profession, Accounting Education, Vocational Accounting Graduates

Jel Classification: $M 40, M 41$

\footnotetext{
*Yrd. Doç. Dr. Gülsevil Yıldız, Erciyes Üniversitesi, Uygulamalı Bilimler Yüksekokulu, yildizg@erciyes.edu.tr
} 


\section{GíRiş}

Günümüzde küreselleşmeye ve ekonomik gelişmelere paralel olarak işletmelerin yaptıkları işlemler daha karmaşık bir hale gelmiştir. Gelişen ekonomik sistem içerisinde, işletmelerin rekabet yeteneklerini koruyabilmeleri ve geleceğe yönelik doğru kararlar alabilmeleri için ihtiyaç duydukları bilgilerde artı̧ olmuştur. $\mathrm{Bu}$ durum, hem muhasebe mesleğinin önemini, hem de hazırlayacakları raporlarla işletme içi ve işletme dışı kişi ve kuruluşlara; doğru, zamanlı ve güvenilir bilgi sağlamakla yükümlü olan muhasebe meslek mensuplarının görev ve sorumluluklarını ve aynı zamanda meslek mensuplarından beklentileri de artırmıştır.

Bilindiği gibi muhasebe, işletme ile ilgili finansal olayları tespit eden, kaydeden, sınıflandıran, raporlayıp analiz ederek yorumlayan ve elde edilen bilgileri kurum içi ve kurum dışındaki ilgili kişi ve kuruluşlara sunan bir sistem olarak tanımlanmaktadır. Sistemin başarısı; sunulan bilgilerin kaliteli, zamanlı, doğru ve güvenilir olmasıyla ölçülür. Bu başarıyı yakalayabilmek ise sistemde çalışan meslek mensuplarının nitelikleriyle doğrudan ilişkilidir. Şüphesiz ki muhasebe eğitiminin kalitesi mesleğin kalitesini de belirlemektedir. Dolayısıyla muhasebe mesleğinin geleceğinin, kaliteli muhasebe eğitimine bağlı olduğu söylenebilir.

Araştırmanın amacı, muhasebe meslek mensuplarının meslek yüksekokulu muhasebe programı mezunlarında aradıkları nitelikleri ve öğrencilerin piyasa ihtiyaçlarına cevap verebilecek nitelikte yetiştirilebilmeleri için önerilen değişiklikleri tespit etmek ve böylece meslek yüksekokullarında, iş piyasasının beklentilerini karşılayabilecek özelliklere sahip meslek elemanı yetiştirilmesine katkıda bulunmaktır. Bu anlamda, MYO’nda aldıkları muhasebe eğitimi ile bu mesleğe adım atacak olanların ne derecede yetkinliğe sahip olduğu, Kayseri il merkezinde faaliyet gösteren muhasebe meslek mensuplarının görüşleri doğrultusunda incelenmiştir.

Araştırmanın yöntemi; kavramsal açıklamalar, gözlemsel tespitler, alan çalışması analizleri, sonuçlar ve öneriler bütünlüğü çerçevesinde geliştirilmiş̧ir. Bu bağlamda girişten sonra Türkiye'de MYO'nda muhasebe eğitimi ile ilgili kavramsal tanım, gözlemsel tespitler ve konu ile ilgili literatür özetine yer verilmiştir. Araştırmanın alan çalışması kısmında ise, Kayseri il merkezinde faaliyet gösteren bağımsız muhasebe meslek mensupları üzerinde yapılan anket çalışması sonucunda elde edilen veriler (SPSS 17.0 for Windows) "Sosyal Bilimler için İstatistik Paket Programı" kullanılarak ele alınmış, elde edilen veriler frekansyüzde analizine tabi tutularak açıklanmıştır. Araştırmanın sonuç kısmında ise, analiz sonucunda elde edilen önemli bulgular, kavramsal açıklamalar ve mevzuat düzenlemelerinin içeriği ile ilişkilendirilerek yorumlanmış ve öneriler geliştirilmiştir. Araştırmanın uygulama bölümü ile ilgili teknik bilgileri bölümün başında ayrıca açıklanmıştır. 


\section{KAVRAMSAL ÇERÇEVE}

Mesleki bir eğitim alanı olan muhasebe eğitimi ülkemizde örgün bir yapı içinde, orta öğretim kurumlarında (başta Ticaret Meslek Liseleri (TML) olmak üzere, Anadolu TML, Çok Programlı Liseler ve diğerleri), yükseköğretim seviyesinde ise üniversitelerin muhasebe eğitimi veren dört y1llık ilgili fakültelerinde lisans, yüksek lisans ve doktora düzeyinde ve iki yıllık meslek yüksekokullarının (MYO) muhasebe programlarında önlisans düzeyinde verilmektedir. Tüm bu kurumlarda verilen muhasebe eğitiminin temel amac1, öğrencilere mesleğin gerektirdiği bilgi, beceri ve davranışları kazandırmaktır.

Araştırmamızın konusunu oluşturan meslek yüksekokulları ülkemizde 1975 yılında üniversite kapsamına alınmış ve 1977 yılından itibaren çeşitli alanlarda eğitim ve öğretim vererek çok sayıda meslek elemanı mezun etmiştir. Türkiye'de 2547 sayılı "Yükseköğretim Kanunu" ile meslek yüksekokullarının yasal çerçevesi oluşturulmuş ve yasanın 3. Madde 1 bendinde; "Meslek Yüksekokulu: Belirli mesleklere yönelik ara insan gücü yetiştirmeyi amaçlayan dört yarlyıllık eğitim-ögrretim sürdüren bir yüksek ögretim kurumudur” şeklinde tanımlanmıştır.

Mesleki eğitim denilince akla gelen ilk kurumlar olan meslek yüksekokullarının kuruluşunun özel amacı (misyonu), iş dünyasının ve toplumun ihtiyacı olan nitelikli meslek elemanlarının yetiştirilmesi olarak belirlenmiştir. Böylece toplumsal ve bireysel hedeflere yönelik olarak, belirli bir mesleğin gerektirdiği bilgi-beceri ve davranış yeteneklerinin kazandırılarak, bireyi işletmelerin talepleri ve ihtiyaçları doğrultusunda yetiştirmek hedeflenmiştir. $\mathrm{Bu}$ hedef gerçekleştirildiğinde ise bundan hem birey kendi bilgi ve becerilerine uygun bir istihdama kavuşmak suretiyle yararlanacak, hem de işletmelerin talep ettiği niteliklere sahip, üretim sürecinin aksamadan yürütülmesi açısından istihdam yoluyla toplum faydalanacaktır; diğer bir ifade ile pozitif dışsal ekonomi yaratılmış olacaktır.

Meslek yüksekokulu muhasebe programlarının amacı, ön lisans düzeyinde verilecek eğitimlerle, işletmelerin ihtiyacı olan ön muhasebe elemanlarının yetiştirilmesidir (Özdemir, 2010:103). Muhasebe programı önlisans mezunları aldıkları iki yıllık eğitimlerle, işletmelerin ön muhasebe elemanı ihtiyacını uzun yıllardan beri karşılamış ve karşılamaya da devam etmektedir (Otlu vd.,2012:36). 2008 yılına kadar muhasebe programı mezunlarının kariyer seçeneklerinden biri de "Serbest Muhasebeci" olabilmekti. Bu tarihe kadar ön lisans seviyesinde öğrenim görmüş olanlar ile ticaret liseleri ve maliye meslek liselerinden mezun olanlar, staj şartını yerine getirmiş olmaları halinde, sınav şartı aranmaksızın sadece serbest muhasebeci unvanı ile çalışabilmekteydiler. Staj süresi ön lisans seviyesinde mezun olanlar için 4 yıl, ticaret liselerinden ve maliye meslek liselerinden mezun olanlar için 6 yıl olarak belirlenmişti. 2008 y1lı itibariyle meslek mensubu sayıları Türkiye genelinde; 28.993 SM, 42.686 SMMM ve 3.815 YMM olmak üzere toplam 75.494'tür. 28.993 olan serbest muhasebecilerin eğitim durumu incelendiğinde \%1'inin lisansüstü mezunu, \%26'sının lisans, \%18'inin önlisans, \%48'inin lise ve dengi ve \%7'sini ilköğretim mezunu olduğu görülmektedir (Gücenme Gençoğlu ve İşseveroğlu, 2010:33). 3568 Sayılı Serbest Muhasebeci 
Mali Müşavirlik ve Yeminli Mali Müşavirlik Kanunu'nda 26.07.2008 tarihinde yapılan değişiklikle "Serbest Muhasebeci” unvanının kaldırılmasıyla birlikte muhasebe programı mezunlarının bu seçeneği ortadan kalkmış, yine aynı tarihten itibaren muhasebe programı önlisans mezunlarına verilen diplomalarda "meslek elemanı" unvanı kaldırılmış ve diplomalarda "yüksekokul mezunu" ibaresi yer almıştır. Her iki uygulama da bölümü okuyan öğrenciler aleyhine bir durum oluşturmakta ve aynı zamanda meslek yüksekokullarının kuruluş misyonları ile ters düşmektedir (Otlu vd.,2012:46). Bununla birlikte önlisans mezunlarının gerek dikey geçiş sınavları ile gerekse Anadolu Üniversitesi Açık Öğretim Fakültesi'nin ilgili bölümlerine sınavsız geçiş yaparak lisans tamamlama hakları bulunmaktadır. Bu hakkı kullanarak bugün SMMM olarak görev yapmakta olan çok sayıda meslek mensubu olduğu da bir gerçektir..

\section{LITERATÜR ÖZETİ}

Türkiye'de Yükseköğretim içinde meslek yüksekokullarının ve bu okullarda açılan muhasebe programlarının sayısı her geçen gün artmakta ve artan sayıyla birlikte yaşanan sorunlar da artmış ve çözülmeyi beklemektedir. Özellikle 2002-2003 eğitim-öğretim döneminden itibaren uygulamaya konulan MYO'na sınavsız geçiş sistemiyle birlikte ciddi sorunlar yaşandığı yapılan araştırmalarla ortaya konulmuştur. Genel olarak meslek yüksekokullarında ve özelde muhasebe programlarında verilen eğitim ve başarı durumuyla ilgili olarak, Türkiye'de son on yıllık dönemde çok sayıda araştırma yapılmış ve sorunlar tespit edilerek çözüm önerileri geliştirilmiştir.

Kızgın (2005) tarafından sınavsız geçiş sistemi ile gelen öğrencilerin başarı durumları üzerine Muğla ilinde yapılan araştırmada; “sınavsız olarak doğrudan MYO’larına gelen öğrencilerin başarıları ile sınavla gelen öğrencilerin aynı derslerdeki başarıları karşılaştırılmış ve incelenen tüm programlarda sınavsız gelen öğrencilerin daha başarısız oldukları" tespit edilmiştir. Ayrıca, "sınava girerek üniversite olanağı bulamamış ögrrenciler ile üniversite hakkını yorulmadan elde etmiş ögrencilerin ders dinleme, derse devam etme, okul bitirerek gelecekten bazı beklentiler duymasının aynı olmadı̆̆ ’” vurgulanmıştır.

Tunç (2005) tarafından meslek yüksekokullarına sınavsız geçişin değerlendirilmesi üzerine yapılan araştırmada; meslek liselerinden meslek yüksekokullara sınavsız geçişin öğrencileri "nasıl olsa meslek yüksekokuluna yerleştirileceği”" anlayışı nedeniyle üniversite sınavı için çaba göstermekten alıkoyduğunu; meslek liselerinden yeterli donanımı elde etmeden gelen ögrrencilerin meslek yüksekokullarında başarıyı düşürdü̈̆̈̈̈nü, meslek yüksekokullarından ayrılma oranlarının yüksek olduğunu ve bunun sonucunda meslek yüksekokulu ögrencilerinin kalitesinin düştüğ̈̈” tespit edilmiştir.

Demir - Subaşı (2008) tarafından muhasebe programlarına sınavsız geçiş yapan öğrencilerin profillerini ve muhasebe mesleğine bakış açılarını tespit etmeye yönelik yapılan araştırmada; "Eskişehir ve Bilecik illerindeki meslek liselerinde okuyan ögrrencilerin meslek yüksekokullarına sınavsı geçiş hakları olmasına răgmen çok az ögrencinin bu hakkı 
kullanmak istediği, büyük çoğunluğunun (\%94,3) özellikle Anadolu Ticaret Meslek Liselerinde öğrenim gören ögrrencilerin ÖSS’ye girerek bir yüksekögrretim programına yerleştirilmek istediği" ortaya konulmuştur. ÖSS'ye giren ancak başarılı olmadiğ $\breve{g}_{\text {takdirde }}$ sınavsız geçiş hakkından yararlanarak meslek yüksekokullarına gitmek isteyen öğrencilerin oranı ise \%78,4 olarak tespit edilmiştir.

Gücenme Gençoğlu-İşseveroğlu (2010) tarafından meslek yüksekokullarındaki eğitimin muhasebe mesleğine katkısı üzerine yapılan araştırmada; "ilk olarak 2002-2003 döneminde ticaret liselerinden MYO’na sınavsız geçiş sisteminin başlamasıyla birlikte MYO'nda eğitim-öğretim kalitesinin düştüğü ve birçok sorunu da beraberinde getirdiği, lise yıllarında yeterince mesleki yönlendirme yapılmadı̆̆ için birçok MYO öğrencisinin

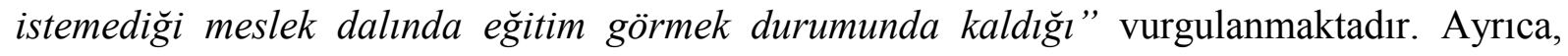
2004 yılında meslek mensubu olabilmek amacıyla staja başlama sinavına katılanlar arasında lisans mezunlarının başarı oranı \%16 iken önlisans mezunlarının başarı oranı \%17 olarak daha yüksek paya sahip olduğu ancak yıllar itibariyle meslek yüksekokullarının sayısı artarken sınava katılanların sayısında artış olmadı̆̆l, bilakis önlisans mezunlarının aleyhine düşme olduğu tespit edilmiştir. MYO sayısının artmasına rağmen başarının azalmasının nedenleri olarak sınavsız geçiş sistemi ve ögrencilerin meslek motivasyonlarının yetersizliği gösterilmektedir.

Demir-Çam (2006) tarafından muhasebe bölümü öğrencilerinin muhasebe öğreniminde başarılarını etkileyen faktörleri belirlemeye yönelik yapılan araştırmada; “ögrencilerin \%58,4'ünün sinavsız geçiş sistemini doğru bulmadiğını, sinavsız geçiş sistemiyle birlikte sinıf içinde hedef birliğinin kaybolduğu ve bu durumun başarlyı olumsuz etkileyen bir faktör olduğu” tespit edilmiştir.

Yardımcıoğlu - Büyükşalvarcı (2007) tarafından Selçuk Üniversitesi meslek yüksekokullarında muhasebe eğitimi alan öğrencilerin meslek yüksekokullarını tercih etme nedenlerini belirlemeye yönelik yapılan araştırmada; “ögrencilerin \%67,8'lik kısmı okudukları bölümü sevmemelerine karşın çeşitli nedenlerden dolayı istekleri dışında bölümlerde eğitim gördüklerini” belirlemişlerdir. "Mesleği sevdiği için bölümde okuyan ögrencilerin orant ise \%32,2 olarak” tespit edilmiştir.

Nartgün - Yüksel (2009) tarafından sınavsız geçişte izlenen kriterlerin değerlendirilmesine yönelik öğretim elemanları üzerine yapılan araştırmada; ̈̈ğretim elemanlarının sınavsız geçiş sisteminin değiştirilmesi ve yeniden düzenlenmesi gerektiğini, sistemin meslek yüksekokullarında öğrenci ve ögretim kalitesini düşürdüğünden şikâyetçi olduklarını tespit etmişlerdir.

Otlu-Durmuş-Solak (2012) tarafindan Malatya ilinde, meslek yüksekokulları muhasebe ve vergi bölümlerindeki muhasebe eğitimi ve bölümün geleceği hakkında yapılan araştırmada; öğrencilerin \%52,8'inin 3568 sayll yasada "Serbest Muhasebeci" unvanının kaldırılmasıyla ilgili olarak yapılan değişiklikten haberdar olmadı ̆̆ $, \% 47,2$ 'sinin bilgi sahibi 
olduğu tespit edilmiştir. 3568 sayıl yasadaki değişiklik hakkında bilgi sahibi olmayanların \%64'ünün, değişiklik hakkında bilgi sahibi olmalarl durumunda bölümlerini tercih etmeyeceklerini bildirdiği görülmüştür. Yine bu tarihten itibaren muhasebe ve vergi bölümlerinden mezun olan öğrencilere verilen diplomalar da "meslek elemanı" unvanının kaldırılarak "yüksekokul mezunu” ibaresinin kullanılmaya başlanması bölümde okuyan ögrenciler aleyhine bir durum oluşturduğu ifade edilmiştir. Araştırmada bu değişikliklerin ön lisans öğrencilerinin meslek motivasyonlarını da olumsuz yönde etkilediği yorumu yapılmıştır.

Kuşat (2014) tarafından meslek yükssekokullarında öğrenci başarısı üzerine Eğirdir MYO muhasebe programı öğrencileri üzerinde yapılan araştırmada, “öğrenci kalitesinin düşı̈̈̆̆̈̈, hem düz lise hem meslek lisesi mezunlarının mesleki derslerde zorlandıkları, sinavlı ya da sınavsı gelmiş olmaları, ögrencilerin kı ya da erkek olmalarının ders başarıları üzerinde farklılık yaratmadı̆̆l, birinci ögretime kayıt yaptıran öğrencilerin ikinci öğretime kayıt yaptıranlardan daha başarılı oldukları" tespit edilmiştir. Yapılan çalışmada "araştırllması ve çözüm üretilmesi gereken konunun, sinavsiz geçiş ya da sinavsı geçişin ortaya çıkardı̆̆ düşünülen meslek yüksekokulu kalitesindeki azalışlar değil, hem düz lise hem de meslek liselerindeki eğitim kalitesindeki düşüşler olduğu” ifade edilmiştir.

Yıldız -Durak (2011) tarafından üniversitelerde verilen muhasebe eğitiminin Kırklareli Yöresi'nde faaliyet gösteren küçük ve orta büyüklükteki işletmelerin beklentilerini karşılama düzeyini inceleyen araştırmada, "Türkiye'de üniversitelerde verilen muhasebe ĕgitiminin (önlisans ve lisans düzeyinde) işletmelerin taleplerini tam olarak karşılamadĭ̆gl”, ve ayrıca, "işletmelerin muhasebe eğitimine gereken önemi vermedikleri, özellikle yetişmiş elemanları istihdam etme e ğiliminde oldukları” tespit edilmiştir.

Ünal - Helhel (2010) tarafindan muhasebe meslek mensuplarının meslek yüksekokulu öğrencilerinin nitelikli yetiştirilmesi hakkında görüş ve beklentilerini tespit etmeye yönelik olarak Antalya ilinde yaptıkları araştırmada, “meslek yüksekokullarında uygulamaya dönük eğitimin oldukça yetersiz olduğu, ögretim elemanlarının büyük bir çoğunluğunun teorik bilgileri aktardıkları ve güncel konularda uygulamaları bilmedikleri, müfredatın piyasa gerçeklerinin gerisinde kaldiğl, mesleki İngilizce ĕgitiminin yetersiz olduğu ancak meslek mensuplarının bu konuda mezunların geliştirilmesi için MYO eğitim camiasından fazla bir beklentilerinin olmadı̆̆ eğitime ă̆ırlık verilmesi, işini benimseyen, ekip çalışmasına yatkın, kendini geliştirmeye, ögrenmeye istekli” bireylerin yetiştirilmesi olarak ifade edilmiştir.

Genel olarak Türkçe literatüre bakıldığında son on yılda yapılan çalışmaların hemen hemen hepsinde ortak sorunların devam etmekte olduğu görülmektedir. Bu da tespit edilen sorunların çözümüne yönelik olarak ciddi çalışmaların yapılamadığını, ilgili kurumlar arasında işbirliklerinin geliştirilemediğini ortaya koymaktadır. 


\section{ALAN ARAŞTIRMASI}

\subsection{Alan Araştırmasının Amacı}

Alan araştırmasının amacı, muhasebe meslek mensuplarının meslek yüksekokulu muhasebe programı mezunlarında aradıkları nitelikleri ve öğrencilerin piyasa ihtiyaçlarına cevap verebilecek nitelikte yetiştirilebilmeleri için önerilen değişiklikleri tespit etmek ve böylece meslek yüksekokullarında, iş piyasasının beklentilerini karşılayacak nitelikte meslek elemanı yetiştirilmesine katkıda bulunmaktır.

\subsection{Alan Araştırmasının Yöntemi}

Alan araştırmasında veriler, birinci kaynaktan veri elde etmede en yaygın yöntem olarak kullanılan anketle soru sorma tekniği kullanılarak, muhasebe meslek mensupları ile bire bir yapılan görüşmeler sonucu elde edilmiştir. Anket uygulamasında; Ünal ve Helhel (2010) tarafından konu ile ilgili Antalya ilinde uygulanan anket formundan faydalanılmıştır.

Anket iki bölümden oluşmaktadır. Birinci bölümde meslek mensuplarının genel özelliklerini ve meslek yüksekokulu muhasebe programı mezunu istihdam edip etmediklerini belirlemeye yönelik 5 soru, ikinci bölümde ise meslek mensuplarının meslek yüksekokulu muhasebe programlarında verilen eğitim ve öğretim düzeyini değerlendirmelerine ve ayrıca mezunların niteliklerini iyileştirmeye yönelik meslek yüksekokullarından beklentilerini ölçmeye yönelik 5'li likert ölçeğinde tanımlanan 32 adet ifade yer almaktadır. Ölçekte 1: Kesinlikle Katılmıyorum, 5: Kesinlikle Katılıyorum şeklinde tanımlanmıştır. Alan araştırması sonucu elde edilen veriler (SPSS 17.0 for Windows) "Sosyal Bilimler için İstatistik Paket Programı" kullanılarak analiz edilmiştir. Verilerin analizinde; frekans (sayı) ve yüzde tekniklerinden yararlanılmıştır.

\subsection{Alan Araştırmasının Kapsamı}

Alan araştırması Kayseri il merkezinde gerçekleştirilmiştir. Alan araştırması için Kayseri il merkezinin seçilmesinde, araştırmacının Kayseri'de bulunması ve zamanın ve finansal olanakların en iyi şekilde değerlendirilmesi düşüncesi etkili olmuştur. Alan araştırmasının ana kütlesini, Kayseri SMMM Odası'na kayıtlı, Serbest Muhasebeci ve Mali Müşavir unvanıyla faaliyet gösteren ve bağımsız olarak fiilen çalışan 449 meslek mensubu oluşturmaktadır. Anket uygulanması gönüllülük esasına dayandığı ve tüm evrene ulaşmanın güç olması nedeniyle evreni temsil eden bir örneklem alanı belirlenmiştir. Araştırmada, kolay uygulanabilen, hizlı ve ucuz yoldan veri elde etmenin en kestirme yolu olan kolayca örnekleme yöntemi (Nakip, 2006: 184) kullanılarak, Kayseri il merkezinde muhasebe meslek mensuplarının kümelendikleri iş merkezleri belirlenmiş ve ana kütle içinden 110 meslek mensubu ile birebir görüşme yapılmak suretiyle veriler elde edilmiştir. Örneklemede, ana kütlenin yaklaşık \%25'ine ulaşılmıştır. 


\subsection{Alan Araştırması Sonuçlarının Analizi}

Araştırma verilerinden elde edilen sonuçlar aşağıdaki grafik ve tablolar aracılığı ile frekans (sayı) ve yüzde analizine tabi tutulmuş ve yorumlanmıştır. Grafik1'de ankete katılan meslek mensuplarının eğitim açısından dağılımı yer almaktadır.

Grafik 1. Eğitim Durumu

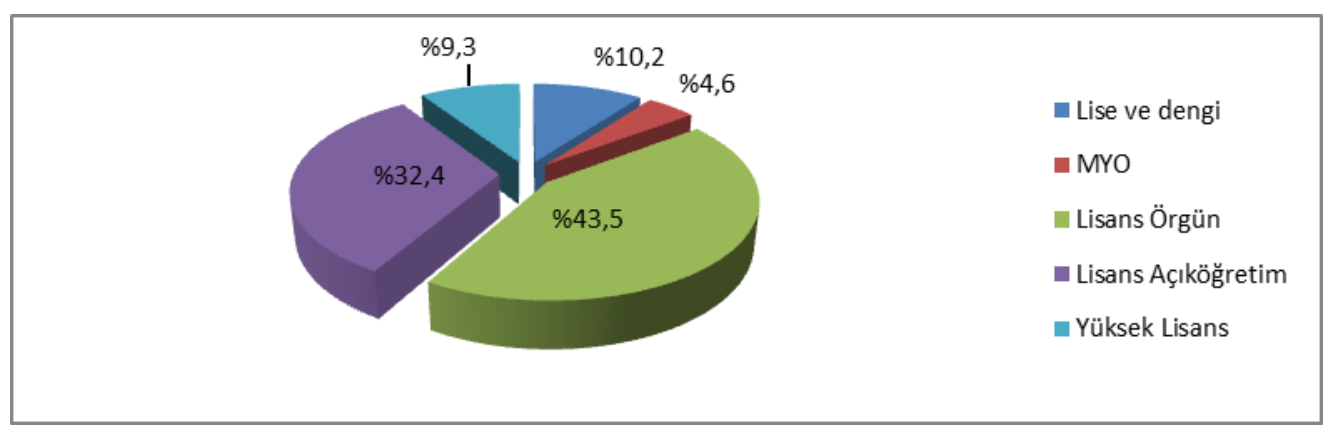

Araştırmaya katılan meslek mensuplarının \%93'ü erkek ve bunların \%98’i serbest muhasebeci mali müşavir unvanına sahiptir. SMMM unvanına sahip meslek mensuplarının \%90’1 önlisans, lisans ve lisansüstü eğitim düzeyine ve \%10'u ise lise ve dengi eğitim düzeyine sahiptir. Önlisans, lise ve dengi eğitim düzeyine sahip meslek mensupları 2008 yılında yasada yapılan değişiklik ile geçici 11. maddede belirtilen haktan faydalanarak stajlarını başarıyla tamamlamışlar ve belirtilen süreçte sınavlara girerek serbest muhasebeci mali müşavir unvanını almışlardır. Araştırmaya katılan meslek mensuplarından sadece \%7'si kadın olup, tamamı serbest muhasebeci mali müşavir unvanına ve lisans ve lisansüstü eğitim düzeyine sahiptir. Bu durum muhasebe mesleğinin kadınlar tarafından çok tercih edilen bir meslek olmadığını ortaya koymaktadır. Çalışmaya katılan 2 serbest muhasebeci meslek mensubundan biri lise ve dengi okul mezunu olduğunu belirtirken diğeri bu soruyu boş bırakmıştır. Söz konusu serbest muhasebeciler 2008'den önce bu unvanı almış ve hâlâ faaliyetine devam etmekte olan meslek mensuplarıdır. ${ }^{1}$

Muhasebe meslek elemanı olarak iş hayatına katılan MYO muhasebe programı mezunlarının meslek mensupları tarafından istihdam edilme durumları Grafik 2'de gösterilmiştir.

\footnotetext{
13568 sayılı yasada değişiklik yapan 5786 sayılı Kanun'un geçici 11. maddesine göre 2007'den önce SM ünvanına sahip olanların TÜRMOB tarafından verilen mesleki uyum eğitimine katılarak bu eğitimi tamamladıkları tarihten itibaren beş yıl içinde yapılacak özel serbest muhasebeci malî müşavirlik sınavlarına beş defa girebilmesi öngörülmüştür. Söz konusu özel sınavlarda başarılı olamayan veya sınava katılmayanlara ise, serbest muhasebeci unvanı ile çalışma hakkı tanınmıştır. Ancak bunların SMMM unvanını kullanamayacakları, çalışma konularının defter tutma ile sınırlı olduğu, meslek mensuplarına ilişskin düzenlemelere tabi oldukları da belirtilmiştir.
} 
Grafik 2. İstihdam Durumu

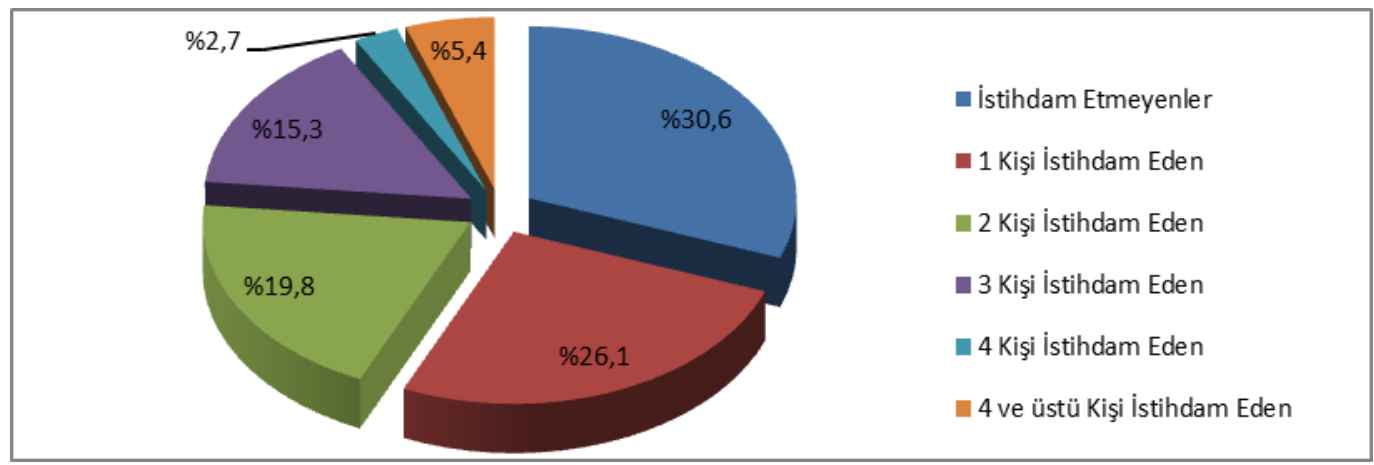

Grafik 2'de, araştırmanın yapıldığı dönemde, araştırmaya katılan muhasebe meslek mensuplarının yaklaşık \%69'unun MYO muhasebe programı mezunu meslek elemanı istihdam ettikleri, yaklaşık \%31'inin ise istihdam etmedikleri görülmektedir. Araştırma meslek mensuplarının \%26,1'inin en az bir muhasebe meslek elemanı kişiyi istihdam ettiklerini ortaya koymaktadır. Dört ve daha fazla muhasebe meslek elemanı istihdam eden meslek mensuplarının oranı $\% 5$ olarak görülmektedir.

Araştırmaya katılan meslek mensuplarının, MYO muhasebe programında verilen eğitim ve öğretimi değerlendirmelerine yönelik 5'li likert ölçeğinde tanımlanan ifadelere yaklaşımları 1 nolu tabloda gösterilmiştir.

Tablo 1. Meslek Mensuplarının MYO’ ndaki Eğitimi Değerlendirmeleri

\begin{tabular}{|l|l|c|c|c|c|c|}
\hline \multicolumn{1}{|c|}{ İfadeler } & & $\mathbf{1}$ & $\mathbf{2}$ & $\mathbf{3}$ & $\mathbf{4}$ & $\mathbf{5}$ \\
\hline Teorik eğitimi yeterli buluyorum. & Frekans & 16 & 37 & 5 & 33 & 19 \\
& & & & & & \\
\cline { 2 - 7 } & Yüzde & $\mathbf{1 4 , 5}$ & $\mathbf{3 3 , 6}$ & $\mathbf{4 , 5}$ & $\mathbf{3 0}$ & $\mathbf{1 7 , 3}$ \\
\hline Uygulamalı eğitimi yeterli buluyorum. & Frekans & 18 & 42 & 10 & 21 & 19 \\
\cline { 2 - 7 } & Yüzde & $\mathbf{1 6 , 4}$ & $\mathbf{3 8 , 2}$ & $\mathbf{9 , 1}$ & $\mathbf{1 8 , 2 9}$ & $\mathbf{1 7 , 3}$ \\
\hline Uygulanan müfredat günceldir. & Frekans & 9 & 27 & 20 & 34 & 18 \\
\cline { 2 - 7 } & Yüzde & $\mathbf{8 , 3}$ & $\mathbf{2 5}$ & $\mathbf{1 8 , 5}$ & $\mathbf{3 1 , 5}$ & $\mathbf{1 6 , 7}$ \\
\hline Bilgisayar öğretimini yeterli buluyorum. & Frekans & 13 & 44 & 15 & 26 & 12 \\
\cline { 2 - 7 } & Yüzde & $\mathbf{1 1 , 8}$ & $\mathbf{4 0}$ & $\mathbf{1 3 , 6}$ & $\mathbf{2 3 , 6}$ & $\mathbf{1 0 , 9}$ \\
\hline Staj süresini yeterli buluyorum. & Frekans & 29 & 30 & 5 & 28 & 18 \\
\cline { 2 - 7 } & Yüzde & $\mathbf{2 6 , 4}$ & $\mathbf{2 7 , 3}$ & $\mathbf{4 , 5}$ & $\mathbf{2 5 , 5}$ & $\mathbf{1 6 , 4}$ \\
\hline
\end{tabular}

Ölçek Değerleri; 1=Kesinlikle Katılmıyorum, 5= Kesinlikle Katıliyorum

Tablo 1'de yer alan cevapların dağılımına genel olarak bakıldığında, tabloda yer alan ifadelerden "Uygulanan müfredat günceldir." ifadesi dışındaki tüm ifadeleri yetersiz bulan meslek mensuplarının oranının, yeterli bulanların oranından daha fazla olduğu görülmektedir. Kararsızlar dikkate alınmadığında, teorik eğitimi yeterli bulanların oranı $\% 47,3$, yetersiz bulanların oranı $\% 48,1$; uygulamalı eğitimi yeterli bulanların oranı $\% 36,4$, yetersiz bulanların oran1 \%54,6; bilgisayar eğitimini yeterli bulanların oran1 $\% 34,5$, yetersiz bulanların oranı $\% 51,8$; staj süresini yeterli bulanların oran1 $\% 41,9$; yetersiz bulanların oranı $\% 53,7$ olarak hesaplanmıştır. Araştırmaya katılan meslek mensuplarının \%33,3'ü müfredatın güncel olmadığını buna karşılık \%48,2'si müfredatın güncel olduğunu ifade etmişlerdir. Ancak bu ifade karşısında kararsız kalanların oranı $(\% 18,5)$ oldukça yüksek çıkmıştır. Meslek 
mensuplarının genel olarak yetersiz buldukları eğitim ve öğretim ile ilgili olarak, söz konusu yetersizlikleri ortadan kaldırabilmek için meslek yüksekokulu muhasebe programlarından beklentilerinin tespit edilmeye çalışıldığı Tablo 6'da yer alan ifadelere bakıldığında, meslek mensuplarının \%90'nının uygulamalı eğitim verilmesi ve \%86,4'ünün müfredatın güncellenmesi gerektiğini ifade ettikleri görülmektedir.

Meslek mensuplarının eleman alırken dikkate aldıkları kriterleri belirlemeye yönelik olarak hazırlanan ifadeler ve meslek mensuplarının cevapları Tablo 2'de yer almaktadır.

Tablo 2. Meslek Mensuplarının Eleman Seçerken Önem Verdikleri Ölçütler

\begin{tabular}{|l|l|c|c|c|c|c|}
\hline \multicolumn{1}{|c|}{ Ifadeler } & & $\mathbf{1}$ & $\mathbf{2}$ & $\mathbf{3}$ & $\mathbf{4}$ & $\mathbf{5}$ \\
\hline Alanında eğitimli olmas1 & Frekans & 7 & 20 & 2 & 36 & 43 \\
\cline { 2 - 7 } & Yüzde & $\mathbf{6 , 4}$ & $\mathbf{1 8 , 3}$ & $\mathbf{1 , 8}$ & $\mathbf{3 3}$ & $\mathbf{3 9 , 4}$ \\
\hline \multirow{2}{*}{ Tecrübeli olması. } & Frekans & 12 & 30 & 5 & 32 & 31 \\
\cline { 2 - 7 } & Yüzde & $\mathbf{1 0 , 9}$ & $\mathbf{2 7 , 3}$ & $\mathbf{4 , 5}$ & $\mathbf{2 9 , 1}$ & $\mathbf{2 8 , 2}$ \\
\hline \multirow{2}{*}{ Güvenilir olması. } & Frekans & 6 & 14 & 2 & 20 & 67 \\
\cline { 2 - 7 } & Yüzde & $\mathbf{5 , 5}$ & $\mathbf{1 2 , 7}$ & $\mathbf{1 , 8}$ & $\mathbf{1 8 , 2}$ & $\mathbf{6 1 , 8}$ \\
\hline Yeniliklere açık olması. & Frekans & 7 & 13 & 4 & 27 & 59 \\
\cline { 2 - 7 } & Yüzde & $\mathbf{6 , 4}$ & $\mathbf{1 1 , 8}$ & $\mathbf{3 , 6}$ & $\mathbf{2 4 , 5}$ & $\mathbf{5 3 , 6}$ \\
\hline Çalışkan ve sorumluluk sahibi olması. & Frekans & 9 & 12 & 2 & 21 & 66 \\
\cline { 2 - 7 } & Yüzde & $\mathbf{8 , 2}$ & $\mathbf{1 0 , 9}$ & $\mathbf{1 , 8}$ & $\mathbf{1 9 , 1}$ & $\mathbf{6 0}$ \\
\hline Kişisel yetenek ve bilgi sahibi olması. & Frekans & 7 & 16 & 4 & 32 & 51 \\
\cline { 2 - 7 } & Yüzde & $\mathbf{6 , 4}$ & $\mathbf{1 4 , 5}$ & $\mathbf{3 , 6}$ & $\mathbf{2 9 , 1}$ & $\mathbf{4 6 , 4}$ \\
\hline Referanslı olması. & Frekans & 8 & 21 & 12 & 39 & 29 \\
\cline { 2 - 7 } & Yüzde & $\mathbf{7 , 3}$ & $\mathbf{1 9 , 2}$ & $\mathbf{1 1}$ & $\mathbf{3 5 , 8}$ & $\mathbf{2 6 , 6}$ \\
\hline
\end{tabular}

Ölçek Değerleri; 1=Kesinlikle Katılmıyorum, 5= Kesinlikle Kat1liyorum

Araştırmaya katılan meslek mensuplarının eleman alırken dikkate aldıkları kriterler sırasıyla; \%80 oranında "güvenilir olma ", \%79,1 oranında "çalışkan ve sorumluluk sahibi olma" ve \%78,1 oranında "yeniliklere ve öğrenmeye açık olma" şeklinde belirlenmiştir. "Tecrübeli olma" kriteri ise meslek mensuplarının en az önem verdikleri kriter $(\% 57,3)$ olarak tespit edilmiştir. Meslek mensupları için, mezunların güvenilir, çalışkan ve sorumluluk sahibi, yeniliklere açık olmaları, tecrübeli olmalarından daha önemli olduğu anlaşılmaktadır.

Meslek mensuplarının meslek yüksekokulu muhasebe programı mezunlarının niteliklerinin iyileştirilmesine yönelik beklentilerini belirlemeye yönelik olarak hazırlanan ifadeler ve meslek mensuplarının cevapları Tablo 3'da yer almaktadır.

Tablo 3. Meslek Mensuplarının MYO Muhasebe Programlarından Beklentileri

\begin{tabular}{|l|l|c|c|c|c|c|}
\hline \multicolumn{1}{|c|}{ İfadeler } & & $\mathbf{1}$ & $\mathbf{2}$ & $\mathbf{3}$ & $\mathbf{4}$ & $\mathbf{5}$ \\
\hline Uygulamalı eğitim verilmesi. & Frekans & 4 & 7 & 0 & 30 & 68 \\
\cline { 2 - 8 } & Yüzde & $\mathbf{3 , 6}$ & $\mathbf{6 , 4}$ & $\mathbf{0}$ & $\mathbf{2 7 , 3}$ & $\mathbf{6 1 , 8}$ \\
\hline Müfredatın güncellenmesi. & Frekans & 2 & 5 & 8 & 32 & 63 \\
\cline { 2 - 7 } & Yüzde & $\mathbf{1 , 8}$ & $\mathbf{4 , 5}$ & $\mathbf{7 , 3}$ & $\mathbf{2 9 , 1}$ & $\mathbf{5 7 , 3}$ \\
\hline
\end{tabular}




\begin{tabular}{|l|l|c|c|c|c|c|}
\hline Piyasa gerçeklerinin anlatılması. & Frekans & 5 & 6 & 7 & 27 & 65 \\
\cline { 2 - 6 } & Yüzde & $\mathbf{4 , 5}$ & $\mathbf{5 , 5}$ & $\mathbf{6 , 4}$ & $\mathbf{2 4 , 5}$ & $\mathbf{5 9 , 1}$ \\
\hline \multirow{2}{*}{ Üniversite-Sanayi işbirliğinin geliştirilmesi. } & Frekans & 5 & 10 & 10 & 45 & 40 \\
& & & & & & \\
\cline { 2 - 6 } & Yüzde & $\mathbf{4 , 5}$ & $\mathbf{9 , 1}$ & $\mathbf{9 , 1}$ & $\mathbf{4 0 , 9}$ & $\mathbf{3 6 , 4}$ \\
\hline Araştırmacı mezun verilmesi. & Frekans & 5 & 10 & 6 & 33 & 56 \\
\cline { 2 - 6 } & Yüzde & $\mathbf{4 , 5}$ & $\mathbf{9 , 1}$ & $\mathbf{5 , 4}$ & $\mathbf{3 0}$ & $\mathbf{5 0 , 5}$ \\
\hline İletişim ve ekip ruhunun oluşturulması. & Frekans & 3 & 8 & 2 & 37 & 60 \\
\cline { 2 - 6 } & Yüzde & $\mathbf{2 , 7}$ & $\mathbf{7 , 3}$ & $\mathbf{1 , 8}$ & $\mathbf{3 3 , 6}$ & $\mathbf{5 4 , 5}$ \\
\hline İşi benimsemesinin sağlanması. & Frekans & 4 & 3 & 0 & 42 & 61 \\
\cline { 2 - 6 } & Yüzde & $\mathbf{3 , 6}$ & $\mathbf{2 , 7}$ & $\mathbf{0}$ & $\mathbf{3 8 , 2}$ & $\mathbf{5 5 , 4}$ \\
\hline Yeteneğine göre yönlendirme yapılmas1. & Frekans & 4 & 8 & 2 & 41 & 55 \\
\cline { 2 - 6 } & Yüzde & $\mathbf{3 , 6}$ & $\mathbf{7 , 3}$ & $\mathbf{1 , 8}$ & $\mathbf{3 7 , 5}$ & $\mathbf{5 0}$ \\
\hline Branşlaşmanın sağlanması. & Frekans & 5 & 9 & 14 & 36 & 56 \\
\cline { 2 - 6 } & Yüzde & $\mathbf{4 , 5}$ & $\mathbf{8 , 2}$ & $\mathbf{1 1 , 8}$ & $\mathbf{3 3 , 6}$ & $\mathbf{4 1 , 8}$ \\
\hline
\end{tabular}

Ölçek Değerleri; 1=Kesinlikle Katılmıyorum, ......., 5= Kesinlikle Katılıyorum

Meslek mensuplarının meslek yüksekokulu muhasebe programı mezunlarının niteliklerinin iyileştirilmesine yönelik olarak meslek yüksekokulu muhasebe programlarından beklentilerinin başında \%93,6 oranıyla "öğrencinin işi benimsemesinin sağlanması" gelmektedir. İkinci sırada \%90 oranıyla "uygulamalı eğitime ağırlık verilmesi” ve üçüncü sırada ise \%88,1 oranıyla "iletişim becerisine ve ekip çalışmasına yatkın" bireyler olarak yetiştirilmeleri şeklinde sıralanmaktadır. Özetle meslek mensuplarının, işini seven, iletişim kurabilen, ekip ruhuna sahip bireyler yetiştirilmesini ve uygulamalı eğitim verilmesini tercih ettikleri tespit edilmiştir.

Meslek mensuplarının beklentilerini karşılamaya yönelik olarak sektör ile üniversite arasında hangi konularda işbirliği yapılabileceğini belirlemeye yönelik olarak hazırlanan ifadeler ve meslek mensuplarının cevapları Tablo 7'de yer almaktadır.

Tablo 4. Sektör-Üniversite İşbirliğinin Yapılması Gereken Konular

\begin{tabular}{|l|l|c|c|c|c|c|}
\hline \multicolumn{1}{|c|}{ İfadeler } & & $\mathbf{1}$ & $\mathbf{2}$ & $\mathbf{3}$ & $\mathbf{4}$ & $\mathbf{5}$ \\
\hline Stajların takip edilmesi ve denetlenmesi. & Frekans & 7 & 7 & 1 & 31 & 64 \\
\cline { 2 - 6 } & Yüzde & $\mathbf{6 , 4}$ & $\mathbf{6 , 4}$ & $\mathbf{0 , 9}$ & $\mathbf{2 8 , 2}$ & $\mathbf{5 8 , 2}$ \\
\hline \multirow{2}{*}{ Kısmi zamanlı istihdamın sağlanması. } & Frekans & 8 & 10 & 8 & 49 & 35 \\
\cline { 2 - 6 } & Yüzde & $\mathbf{7 , 3}$ & $\mathbf{9 , 1}$ & $\mathbf{7 , 3}$ & $\mathbf{4 4 , 5}$ & $\mathbf{3 1 , 8}$ \\
\hline Mezun istihdamının sağlanması. & Frekans & 6 & 5 & 9 & 46 & 44 \\
\cline { 2 - 7 } & Yüzde & $\mathbf{5 , 5}$ & $\mathbf{4 , 5}$ & $\mathbf{8 , 2}$ & $\mathbf{4 1 , 8}$ & $\mathbf{4 0}$ \\
\hline Öğretim elemanları seminerlerinin yapılması. & Frekans & 7 & 10 & 19 & 36 & 31 \\
& & & & & & \\
\cline { 2 - 7 } & Yüzde & $\mathbf{6 , 8}$ & $\mathbf{9 , 1}$ & $\mathbf{1 8 , 5}$ & $\mathbf{3 5}$ & $\mathbf{3 0 , 1}$ \\
\hline Oda mensuplarına seminerler verilmesi. & Frekans & 8 & 9 & 10 & 41 & 42 \\
\cline { 2 - 7 } & Yüzde & $\mathbf{7 , 3}$ & $\mathbf{8 , 2}$ & $\mathbf{9 , 1}$ & $\mathbf{3 7 , 3}$ & $\mathbf{3 8 , 2}$ \\
\hline Müfredatın güncelliğinin sağlanması. & Frekans & 5 & 2 & 8 & 37 & 58 \\
\cline { 2 - 6 } & Yüzde & $\mathbf{4 , 5}$ & $\mathbf{1 , 8}$ & $\mathbf{7 , 3}$ & $\mathbf{3 3 , 6}$ & $\mathbf{5 2 , 7}$ \\
\hline
\end{tabular}

Ölçek Değerleri; 1=Kesinlikle Katılmıyorum, ......., 5= Kesinlikle Katılıyorum 
Tablo 4 incelendiğinde meslek mensuplarının \%86,4 oranıyla "zorunlu staj uygulamalarında", \% 86,3 oranıla "ders müfredatlarının güncellenmesi” ve \%81,1 oranıla "mezun ögrrencilerin istihdam edilmesi” konularında sektör ve üniversite arasında işbirliği yapılabileceğini ifade ettikleri görülmektedir.

Meslek mensuplarının meslek yüksekokulu muhasebe programı müfredatında yer almasını istedikleri konuları belirlemeye yönelik olarak hazırlanan ifadeler ve meslek mensuplarının cevapları Tablo 5'de yer almaktadır.

Tablo 5. Meslek Mensuplarının Müfredatta Yer Almasını İstedikleri Konular

\begin{tabular}{|l|l|c|c|c|c|c|}
\hline \multicolumn{1}{|c|}{ İfadeler } & & $\mathbf{1}$ & $\mathbf{2}$ & $\mathbf{3}$ & $\mathbf{4}$ & $\mathbf{5}$ \\
\hline Türkiye Muhasebe Standartları & Frekans & 6 & 2 & 5 & 39 & 58 \\
& & & & & & \\
\cline { 2 - 6 } & Yüzde & $\mathbf{5 , 5}$ & $\mathbf{1 , 8}$ & $\mathbf{4 , 5}$ & $\mathbf{3 5 , 4}$ & $\mathbf{5 2 , 7}$ \\
\hline $\begin{array}{l}\text { Vergi Usul Kanunu, Gelir Vergisi ve KDV } \\
\text { Uygulamaları }\end{array}$ & Frekans & 6 & 3 & 0 & 26 & 75 \\
& & & & & & \\
\cline { 2 - 6 } & Yüzde & $\mathbf{5 , 5}$ & $\mathbf{2 , 7}$ & $\mathbf{0}$ & $\mathbf{2 3 , 6}$ & $\mathbf{6 8 , 2}$ \\
\hline Sektörel Maliyet Muhasebesi Uygulamaları. & Frekans & 5 & 8 & 5 & 35 & 57 \\
\cline { 2 - 7 } & Yüzde & $\mathbf{4 , 5}$ & $\mathbf{7 , 3}$ & $\mathbf{4 , 5}$ & $\mathbf{3 0 , 9}$ & $\mathbf{5 1 , 8}$ \\
\hline $\begin{array}{l}\text { Finansal Piyasalar ve Kurumlarla İlgili } \\
\text { Uygulamalar. }\end{array}$ & Frekans & 6 & 8 & 9 & 29 & 58 \\
\cline { 2 - 6 } & Yüzde & $\mathbf{5 , 5}$ & $\mathbf{7 , 3}$ & $\mathbf{8 , 2}$ & $\mathbf{2 6 , 4}$ & $\mathbf{5 2 , 7}$ \\
\hline Muhasebe Meslek Etiğinin Müfredata alınmas1. & Frekans & 5 & 5 & 4 & 29 & 66 \\
\cline { 2 - 6 } & Yüzde & $\mathbf{4 , 5}$ & $\mathbf{4 , 5}$ & $\mathbf{3 , 7}$ & $\mathbf{2 6 , 6}$ & $\mathbf{6 0 , 5}$ \\
\hline
\end{tabular}

Ölçek Değerleri; 1=Kesinlikle Katılmıyorum,

, $5=$ Kesinlikle Kat1liyorum

Tablo 5 incelendiğinde meslek mensuplarının; sırasıyla \%91,8 oranında "Vergi Usul, Gelir Vergisi ve Katma Değer Vergisi uygulamalarına", \%88,1 oranında "Türkiye Muhasebe Standartlarl” ve \%87,1 oranında "Muhasebe Meslek Etiği” konularının müfredata alınmasına önem ve öncelik verdikleri görülmektedir. Bu öncelikler meslek mensuplarının meslek yüksekokulu muhasebe programlarından beklentileri olan, uygulamalı eğitim ve müfredatın güncellenmesi ile örtüşmektedir. "Sektörel Maliyet Muhasebesi” ve "Finansal Piyasalar ve Kurumlarla Ilgili Uygulamalar” ise son sırada yer almaktadır. Sıralama değişse de Ünal ve Helhel tarafindan yapılan araştırmada da benzer sonuca ulaşılmıştır.

\section{SONUÇ VE ÖNERÍLER}

Kayseri SMMMO'na kayıtlı ve bağımsız olarak Kayseri il merkezinde faaliyet gösteren "Serbest Muhasebeci ve Mali Müşavir" unvanlı meslek mensuplarının, MYO muhasebe programı mezunlarından beklentilerini tespit etmeye yönelik olarak yapılan alan çalışmamızın belli başlı bulguları aşağıdaki gibi özetlenebilir; 
- Araştırmaya katılan meslek mensuplarının \%93'ü erkek, \%7'si kadındır. SMMM unvanına sahip meslek mensuplarının \%90'nı önlisans, lisans ve lisansüstü eğitim düzeyine ve \%10'u ise lise ve dengi eğitim düzeyine sahiptir.

- Meslek mensuplarının \%69'u MYO muhasebe programı mezunu istihdam ettiklerini belirtmişlerdir. Meslek mensuplarının \%25'i sadece bir MYO muhasebe programı mezunu istihdam etmektedir. Dört ve daha fazla muhasebe programı mezunu istihdam eden meslek mensuplarının oranı ise $\% 5,4$ 'tür.

- Meslek mensupları tarafından meslek yüksekokulu muhasebe programlarında verilen eğitim ve öğretim, "müfredatın güncel olması, teorik ve uygulamalı eğitim, bilgisayar öğretimi ve staj süreleri” açısından önemli ölçüde yetersiz görülmektedir.

- Meslek mensupları istihdam edecekleri mezunlarda öncelikle "güvenilir olma”, "sorumluluk sahibi ve çalışkan olma" ve "yeniliklere ve ögrrenmeye açık olma" gibi kriterlere öncelik vermektedirler.

- Meslek mezunlarının istenilen niteliklere sahip olabilmesi için "uygulamalı eğitime" ağırlık verilmesi, "müfredatın güncellenmesi”, "iletişim becerisine ve ekip çalışması ruhuna sahip” öğrencilerin yetiştirilmesi meslek mensuplarının öncelikli beklentileri arasindadir.

- "Zorunlu staj uygulamalarl”, “müfredatın güncellenmesi” ve “mezun ögrencilerin istihdam edilmesi” konularında sektör ve MYO arasında işbirliği yapılması önerilmektedir.

Yukarıda sıralanan tespit ve öneriler dikkate alınarak, MYO muhasebe bölümlerinde muhasebe meslek mensuplarının beklentilerini karşılayacak şekilde eğitim ve öğretim verilebilmesi için;

- Sektörel ihtiyaçların belirlenerek müfredatların oluşturulmasının,

- Sektör ve MYO arasında kurulacak işbirliği ile staj uygulamalarının yasal bir zemine oturtulması suretiyle uygulamalı eğitime ağırlık verilmesinin,

- Öğrencilere mesleki bilgi ve becerinin yanı sıra, muhasebe mesleki etik değerlere bağlı, sorumluk sahibi, güvenilir, kolektif çalışmaya, yeniliklere ve öğrenmeye açık olma gibi davranışların kazandırılmasına yönelik eğitim verilmesinin,

- $\quad$ Son olarak, öğrencilerin motivasyonlarını artırmaya yönelik olarak, "sınavsız geçiş sistemi”nin kaldırılmasının, MYO muhasebe bölümü önlisans mezunu olan öğrencilere verilen diplomalarda "meslek elemanı" unvanının yeniden verilmesinin sağlanması gibi "yapısal değişiklikler" gerçekleştirilerek, hem öğrencilerin "zorunlu” olarak değil, tercih ederek gidecekleri MYO'nın oluşturulmasına ve hem de iş piyasasının talep ettiği standartlara sahip meslek elemanı yetiştirilmesine ve böylece istihdama ve ülke ekonomisine olumlu katkılar yaratılacağı kanaatindeyiz. 


\section{KAYNAKLAR}

Demir, Mehmet - Çam Mustafa (2006), "Muhasebe Bölümü Öğrencilerinin Muhasebe Öğreniminde Başarılarını Olumsuz Etkileyen Faktörlere İlişkin Bir Araştırma”, Muhasebe ve Finansman Dergisi, Sayı 32, Ekim, ss.160-169.

Demir, Berna ve Subaşı, Şerife (2008), "Muhasebe Programlarına Sınavsız Geçiş Hakkı Olan Öğrencilerin Profili ve Muhasebe Mesleğine Bakışları”, Muhasebe ve Finansman Dergisi, Sayı 37, Ocak, ss. 88-97.

Gücenme Gençoğlu, Ümit - İşseveroğlu, Gülsün (2010), “Türkiye’de Meslek Yüksekokullarındaki Eğitimin Muhasebe Mesleğine Katkısı Üzerine Bir Araştırma”, Muhasebe ve Finansman Dergisi, Sayı 47, Temmuz, ss. 28-40

İşseveroğlu, Gülsün- Gücenme Gençoğlu, Ümit (2011), “Türkiye’de Meslek Yüksekokullarının Bölge İhtiyaçlarına Uygunluğu Üzerine Araştırma”, Muhasebe ve Finansman Dergisi, Say1 49, Ocak, ss. 24-36

Kızgın, Yıldıray (2005), "Sınavsız Geçiş (METEB) Sistemi İle Gelen Öğrencilerin Başarılarının İstatistiki Analizi: Muğla Üniversitesi Muğla Meslek Yüksekokulu Örneği”, "İş,Güç", Endüstri İlişkileri ve İnsan Kaynakları Dergisi, Cilt 7, Sayı 2, Haziran, ss.120-129.

Kuşat, Nurdan (2014), "Meslek Yüksekokullarında Öğrenci Başarısı Üzerine Bir Çalışma: Eğirdir Meslek Yüksekokulu Muhasebe Programı Örneği”, Muhasebe ve Finansman Dergisi, Say1 49, Ocak, ss.65-79.

Nakip, Mahir (2003), Pazarlama Araştırmaları Teknikler Ve (SPSS Destekli) Uygulamalar, Seçkin Yayıncılık A.Ş. Ankara.

Nartgün, Şenay - Yüksel, Engin (2009), “Meslek Yüksekokullarına Sınavsız Geçişte İzlenen Kriterlerin Değerlendirilmesi”, Abant İzzet Baysal Üniversitesi Dergisi, Cilt 9, Sayı 2, Y1l 9, Aralık, ss.189-204.

Otlu, Fikret - Durmuş, Ahmet Fethi - Solak, Bilal (2012), “Meslek Yüksekokulları Muhasebe ve Vergi Bölümlerindeki Muhasebe Eğitimi Ve Bölümün Geleceği Hakkında Bir Araştırma: Malatya Meslek Yüksekokulu Uygulaması", Muhasebe ve Finansman Dergisi, Sayı 55, Temmuz, ss.35-50.

Özdemir, Serkan (2010), “Önlisans Muhasebe Öğrencilerinin Kariyer Planlanmasını Etkileyen Unsurlar: Ege Bölgesinde Bir Araştırma”, Muhasebe ve Bilim Dünyası Dergisi, Cilt 12, Say12, Haziran, ss.103-122.

Tunç, Adbülkadir (2005), "Meslek Yüksekokullarına Sınavsız Geçişin Değerlendirilmesi”, ZKÜ Sosyal Bilimler Dergisi, Cilt 1, Sayı 2, ss.75-81.

Ünal, Güler Ferhan - Helhel, Yeşim (2010), "Muhasebe Meslek Mensuplarının Meslek Yüksekokulu Öğrencilerinin Nitelikli Yetiştirilmesi Hakkında Görüş ve Beklentileri: 
Antalya İlinde Bir Araştırma”, 9. Ulusal İşletmecilik Kongresi,6-8 Mayıs, Zonguldak, ss.322-326

Yardımcıoğlu, Mahmut - Büyükşalvarcı, Ahmet (2007), "Muhasebe Eğitiminde Meslek Yüksekokullarının Yeterliliği Ve Tercih Edilme Sebepleri”, Muhasebe ve Finansman Dergisi, Ekim, Sayı 36, ss. 173-178.

Yıldız, Fehmi - Durak, Gökhan (2011), "Üniversitelerde Verilen Muhasebe Eğitiminin Kurklareli Yöresi'nde Faaliyet Gösteren Küçük ve Orta Büyüklükteki İşletmelerin Beklentilerini Karşılama Düzeyinin İncelenmesi”, Muhasebe ve Finansman Dergisi, Ocak, Say1 49, ss. 37-47.

3568 Sayılı Serbest Muhasebeci Mali Müşavir ve Yeminli Mali Müşavirlik Kanunu www.yok.gov.tr, 2016 
